\title{
Tsukamurella tyrosinosolvens sp. nov.
}

\author{
A. F. YASSIN, ${ }^{1 *}$ F. A. RAINEY, ${ }^{2} \dagger$ J. BURGHARDT, ${ }^{2}$ H. BRZEZINKA, ${ }^{3}$ S. SCHMITT, ${ }^{4}$ P. SEIFERT,
} O. ZIMMERMANN,${ }^{6}$ H. MAUCH, ${ }^{7}$ D. GIERTH,${ }^{1}$ I. LUX, ${ }^{1}$ AND K. P. SCHAAL ${ }^{1}$

Institut für Medizinische Mikrobiologie und Immunologie der Universität Bonn, 53127 Bonn, ${ }^{1}$ Deutsche Sammlung von Mikroorganismen und Zellkulturen $\mathrm{GmbH}, 38124$ Braunschweig, ${ }^{2}$ Institut für Rechtsmedizin der Universität Bonn, 53111 Bonn, ${ }^{3}$ Institut für Medizinische Mikrobiologie der Universität Bochum, Medizinal-Untersuchungsamt, 44777 Bochum, ${ }^{4}$ Alfried-Krupp Labor, Universität-Augenklinik, D-53105 Bonn, ${ }^{5}$ Staatlisches

Medizinal-Untersuchungsamt, 37075 Göttingen, ${ }^{6}$ and Institut für Mikrobiologie, Immunologie und Laboratoriumsmedizin, Krankenhaus Zehlendorf-Heckshorn, 14109 Berlin, ${ }^{7}$ Germany

\begin{abstract}
Chemotaxonomic and 16S ribosomal DNA sequence analyses of four bacterial isolates from blood cultures from patients with cardiac pacemaker implants and sputa of patients with chronic lung infections clearly demonstrated that these bacteria belong to the genus Tsukamurella. DNA-DNA hybridization data, as well as the physiological characteristics of the isolates, indicate that they are closely related and belong to a single species that differs from previously described members of the genus Tsukamurella. The name Tsukamurella tyrosinosolvens sp. nov. is proposed for these isolates, and the new species is represented by strain IMMIB D-1397 ${ }^{\mathrm{T}}$ (= DSM 44234 ${ }^{\mathrm{T}}$ ). Strain IMMIB D-1397 $7^{\mathrm{T}}$ exhibits 53.4, 53.5, and 54.7\% DNA-DNA relatedness to Tsukamurella paurometabola DSM $20162^{\mathrm{T}}$, Tsukamurella inchonensis DSM $44067^{\mathrm{T}}$, and Tsukamurella pulmonis DSM $44142^{\mathrm{T}}$, respectively.
\end{abstract}

The taxonomic history of the genus Tsukamurella, particularly that of Tsukamurella paurometabola, Tsukamurella inchonensis, and Tsukamurella pulmonis, was recently outlined in detail $(7,37,38)$. Chemotaxonomic data indicate that the genus Tsukamurella is closely related to the genera Mycobacterium, Nocardia, Rhodococcus, Gordona, Dietzia, and Corynebacterium. All of these taxa contain the meso isomer of 2,6diaminopimelic acid and the whole-cell wall sugars arabinose and galactose (i.e., they have cell wall chemotype IV) (20); contain mycolic acids; have a fatty acid profile that includes major amounts of straight-chain saturated, unsaturated, and tuberculostearic acids; have phospholipid type PII sensu Lechevalier et al. (19) (i.e., phosphatidylethanolamine is the characteristic phospholipid); and contain menaquinones as the only respiratory isoprenoid quinones. However, differences in mycolic acid size and detailed chemical structure, as well as differences in menaquinone composition, are very valuable for differentiating between Tsukamurella and related taxa. Thus, the mycolic acids of Tsukamurella strains have chains ranging from 64 to 74 carbon atoms long, contain from one to six double bonds, have no oxygen functions other than the 3-hydroxy group, and release $\mathrm{C}_{20}$ and $\mathrm{C}_{22}$ straight-chain saturated and unsaturated acid derivatives on pyrolysis $(5,8,28,37,38)$. The presence of a fully unsaturated menaquinone having nine isoprene units (MK-9) is another chemotaxonomic characteristic that distinguishes the genus Tsukamurella from other mycolic acid-containing taxa, which usually have dihydrogenated menaquinones $(6,33,37,38)$.

Phylogenetic analyses have demonstrated that the genus Tsukamurella is related to other mycolic acid-containing bacteria belonging to the genera Dietzia, Gordona, Nocardia, Mycobacterium, Rhodococcus, and Corynebacterium (24, 37, 38).

Using chemotaxonomic methods for identification of clinical bacterial isolates, we found that four strains (strains IMMIB

* Corresponding author. Mailing address: Institut für Medizinische Mikrobiologie und Immunologie der Universität Bonn, SigmundFreud-Strasse 25, 53127 Bonn, Germany.

$\dagger$ Present address: Department of Microbiology, Louisiana State University, Baton Rouge, LA.
D-1397 ${ }^{\text {T }}$ IMMIB D-1411, IMMIB D-1437, and IMMIB D-1498) have chemotaxonomic characteristics which suggest that they should be included in the genus Tsukamurella. The results of additional taxonomic and phylogenetic investigations indicated that these organisms belong to a single new species which is different from previously described species of the genus Tsukamurella. In this paper we describe the morphological, chemotaxonomic, physiological, and phylogenetic characteristics of this new species.

\section{MATERIALS AND METHODS}

Bacterial strains. Strains IMMIB D-1397 ${ }^{\top}$ and strain IMMIB D-1411 were isolated more than once from blood cultures from a 62-year-old woman and a 61-year-old man, respectively, both of whom had cardiac pacemaker implants. Strains IMMIB D-1437 and IMMIB D-1498 were isolated from sputa of 68-yearold patients who suffered from chronic lung infections. Two other organisms, $T$ inchonensis DSM $44067^{\mathrm{T}}$ and T. pulmonis DSM $44132^{\mathrm{T}}$, were isolated and described by us previously $(37,38)$. T. paurometabola DSM $20162^{\mathrm{T}}$ was obtained from the German Collection of Microorganisms and Cell Cultures (DSM).

Isolation method. Strains IMMIB D-1397 ${ }^{\top}$ and IMMIB D-1411 were isolated directly from blood cultures which were incubated at $37^{\circ} \mathrm{C}$. Inocula from these cultures were subsequently subcultured on blood agar, chocolate agar, brain heart infusion (BHI) agar, and Muller-Hinton agar. Strains IMMIB D-1437 and IMMIB D-1498 were isolated from sputa after decontamination with $N$-acetylL-cysteine $(15,27)$. The specimens were concentrated by centrifugation at $3,000 \times g$ for $20 \mathrm{~min}$ and were cultured on Loewenstein-Jensen medium.

Morphology and pigmentation. Strains IMMIB D-1397 ${ }^{\mathrm{T}}$, IMMIB D-1411, IMMIB D-1437, and IMMIB D-1498 were grown on yeast extract-malt extract agar (International Streptomyces Project [ISP] medium 2), oatmeal agar (ISP medium 3), and inorganic salts-starch agar (ISP medium 4) as described by Shirling and Gottlieb (26) and were examined for pigmentation, production of aerial hyphae, and other morphological characteristics. Cultures were grown for 4 weeks and observed weekly. Air-dried smears from BHI agar cultures were stained by the Gram and Ziehl-Neelsen methods in order to determine the Gram reaction and acid fastness, respectively. The micromorphology of the organisms was determined by using a culture grown at $37^{\circ} \mathrm{C}$ for 4 days on ISP medium 2 . Electron micrographs of the preparation were taken with a Zeiss digital scanning electron microscope (model DSM 950).

Physiological characteristics. The ability of the isolates to grow at various temperatures $\left(24,31,37\right.$, and $\left.45^{\circ} \mathrm{C}\right)$ was determined after 1 week of incubation on BHI agar. Peptone-yeast extract-iron agar (ISP medium 6) and tyrosine agar (ISP medium 7) as described by Shirling and Gottlieb (26) were used to determine melanoid pigment production. The following properties were determined as described previously: the niacin test was performed by using test strips (Difco Laboratories, Detroit, Mich.) $(13,32)$; nitrate reductase activity was determined by the method of Kubica and David (14): catalase $\left(68^{\circ} \mathrm{C}\right)$ activity was determined by the method of Kubica and Pool (16); arylsulfatase activity (after 3 days) was determined by the method of Kubica and Ridgon (17); $\beta$-glucosidase and $\beta$-ga- 

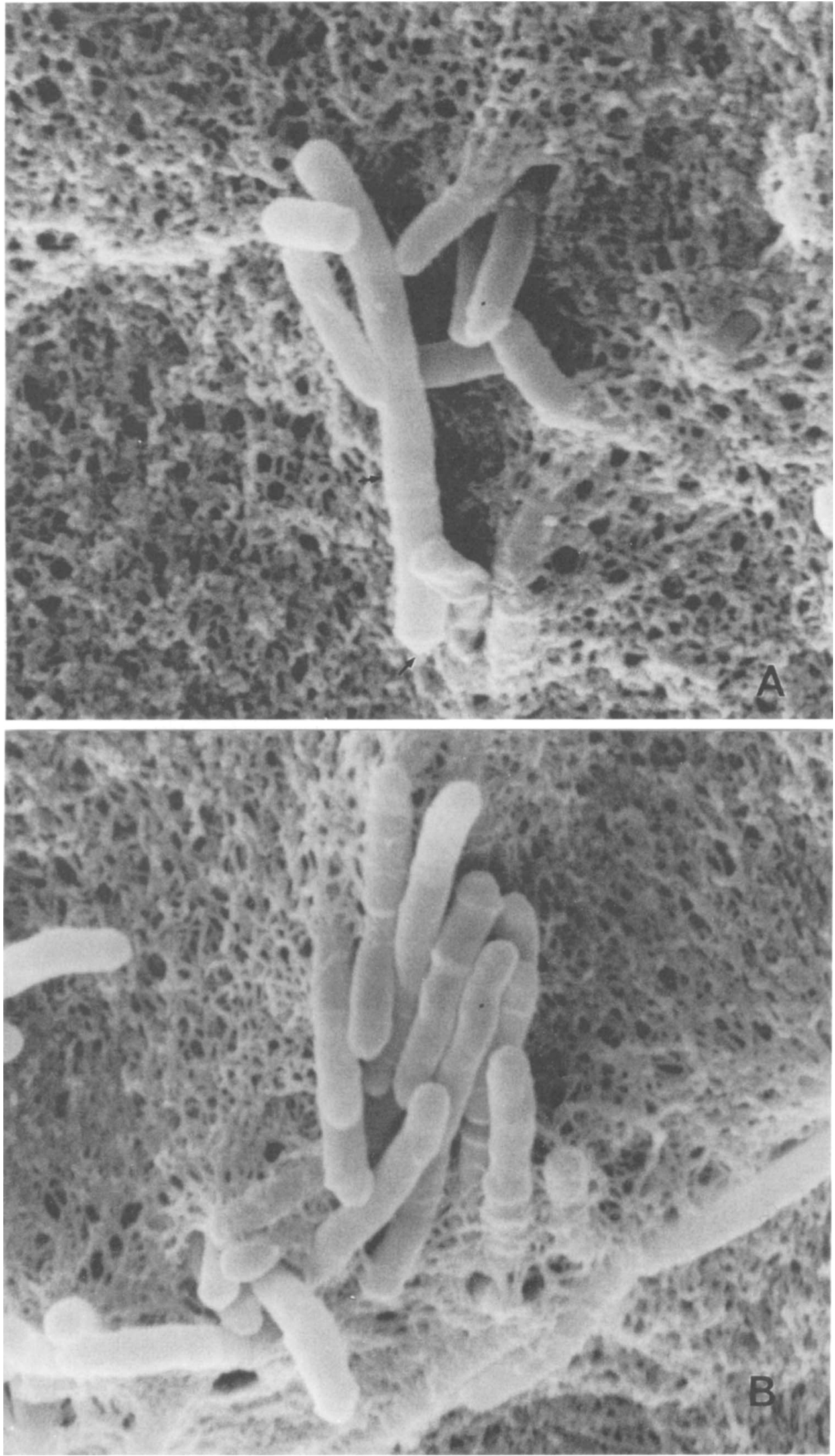

FIG. 1. Scanning electron micrographs of strain IMMIB D-1397 . (A) Long rod-shaped cells with apical transverse septa. (B) Daughter cell growing and the process of septum formation being repeated. (C) After maturation the daughter cells separate by a fragmentation process. Cultures were grown on BHI agar for $12 \mathrm{~h}$ (A and B) and for 4 days $(C)$. 


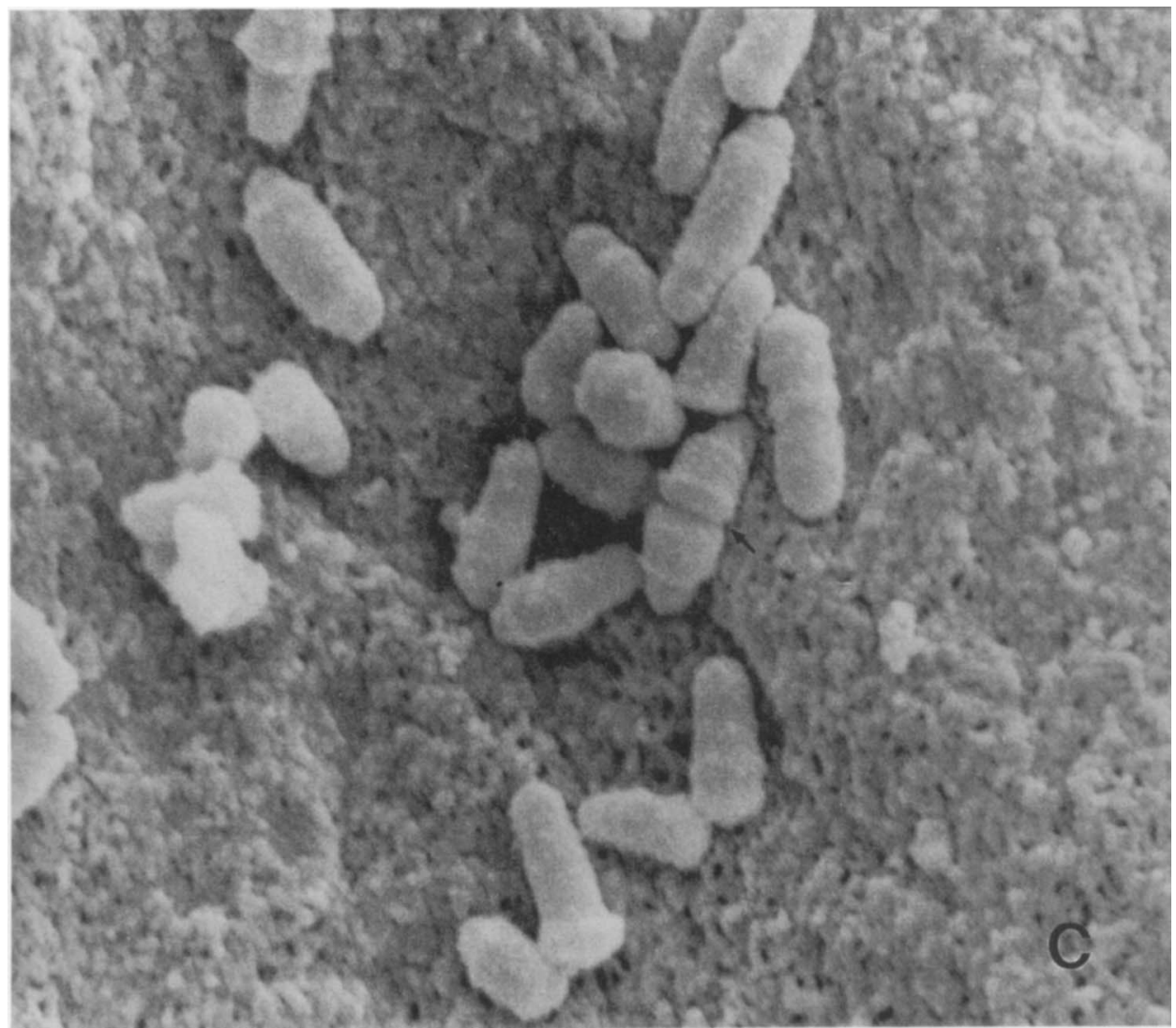

FIG. 1-Continued

lactosidase activities were determined by the method of Tsukamura (29); Tween 80 hydrolysis was determined by the method of Wayne et al. (31); growth on MacConkey agar was determined by the method of Pattyn and Portaels (23); resistance $10 \mathrm{NaCl}$ and $p$-nitrobenzoic acid was determined by the methods of Wayne et al. (31) and Tsukamura and Tsukamura (30); acetamidase, allantoinase, benzamidase, nicotinamidase, pyrazinamidase, succinamidase, and urease activities were determined by the method of Bönicke (2); and resistance to streptomycin $(4.0$ and $8.0 \mu \mathrm{g})$, isoniazid $(0.25$ and $1.0 \mu \mathrm{g})$, ethambutol $(8.0,16.0$, and $32.0 \mu \mathrm{g})$, rifampin $(16.0$ and $32.0 \mu \mathrm{g}$ ), p-aminosalicylic acid (16 and $32.0 \mu \mathrm{g}$ ), protionamide $(16.0$ and $32.0 \mu \mathrm{g})$, capreomycin $(16.0$ and $32.0 \mu \mathrm{g})$, and $\mathrm{cy}-$ closerine $(16.0$ and $32.0 \mu \mathrm{g})$ was determined by using Loewenstein-Jensen slants supplemented with the concentrations of drugs (Biotest) indicated above. Tests to determine decomposition of adenine, guanine, hypoxanthine, xanthine, tyrosine, elastin, keratin, and testosterone were performed by the method of Gordon and Smith (11); the esculin decomposition test was performed by the method of Gordon (9); and casein and gelatin hydrolysis tests were performed by the method of Gordon and Mihm (10). The urea decomposition test was performed by using urea agar base (catalog no. CM 53; Oxoid) after $2.2 \%$ urea had been added. In order to determine whether a substrate was utilized as a carbon source or as a simultaneous carbon and nitrogen source, we used the media described by Yassin et al. (37). Sensitivity to lysozyme was determined as described previously (38).

Cell chemistry. The strains studied were cultivated at $37^{\circ} \mathrm{C}$ in shake flasks containing BHI broth (Difco) for 1 week. After we checked for purity at maximum growth, the organisms were killed with formaldehyde $(1 \%$, vol/vol $)$, harvested by centrifugation, washed with distilled water, and freeze-dried. Analyses of whole-cell hydrolysates for amino acids and sugars were performed by the methods of Becker et al. (1) and Lechevalier (18). Acid methanolysis, alkaline methanolysis, conversion to tert-butyldimethylsilyl (TBDMS) ethers, one-dimensional thin-layer chromatography, two-dimensional thin-layer chromatography, and pyrolysis gas chromatography were performed as previously described by Yassin et al. (34). Menaquinones were extracted and purified by the method of Collins et at. (6) and were identified by using a Finnigan Mat 212 mass spectrometer. Phospholipids were extracted, purified, and identified as described previously (36).

DNA isolation and characterization. Cell mass for DNA-DNA hybridization was obtained as described above for the cell chemistry analysis. DNA was isolated by chromatography on hydroxyapatite by using the method of Cashion et al.
(4). Guanine-plus-cytosine $(\mathrm{G}+\mathrm{C})$ contents were determined by high-performance liquid chromatography (22). DNA-DNA hybridization studies were carried out by using the thermal renaturation method (35).

$16 S$ rDNA sequence determination and analysis. Two to three colonies from BHI agar were used for $16 \mathrm{~S}$ ribosomal DNA (rDNA) sequencing studies. Genomic DNA extraction and PCR-mediated amplification of 16S rDNA genes were performed as described previously (25). Purified PCR products were di rectly sequenced by using a Taq DyeDeoxy terminator cycle sequencing kit (Applied Biosystems, Foster City, Calif.) according to the protocol provided by the manufacturer. An Applied Biosystems model 373A DNA sequencer was used to electrophorese the sequencing reaction mixtures. The $16 \mathrm{~S}$ rDNA sequences determined in this study were manually aligned with previously published sequences available from public databases. Similarity values were calculated by pairwise comparison by using the facilities of the ae 2 editor (21). Phylogenetic dendrograms were generated by using treeing algorithms contained in the PHYLIP package (12).

Nucleotide sequence accession numbers. The $16 \mathrm{~S}$ rDNA sequences of strains IMMIB D-1397 ${ }^{\mathrm{T}}$, IMMIB D-1411, IMMIB D-1437, and IMMIB D-1498 have been deposited in the EMBL data library under accession no. Y12246, Y12248, Y12247, and Y12245, respectively.

\section{RESULTS}

Colonial morphology. Strains IMMIB D-1397 , IMMIB D-1411, IMMIB D-1437, and IMMIB D-1498 grew well on BHI agar and ISP medium 2; on both media the colonies were cream to yellowish and rough. On ISP medium 3 and ISP medium 4, growth was weak and the colonies were leathery. No diffusible pigments were observed. At 24 to $37^{\circ} \mathrm{C}$ growth occurred within 1 to 2 days on BHI agar and ISP medium 2 .

Micromorphology. The cells of strains IMMIB D-1397 ${ }^{\mathrm{T}}$, IMMIB D-1411, IMMIB D-1437, and IMMIB D-1498 were rod shaped, gram positive, and slightly acid-alcohol fast. 


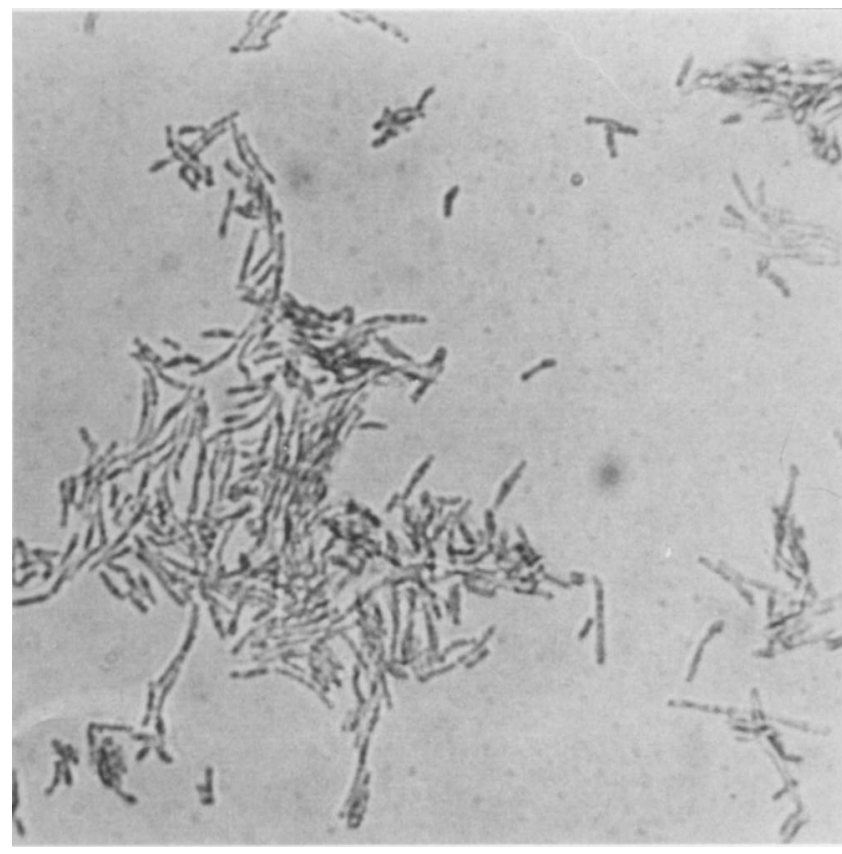

FIG. 2. Phase-contrast micrograph of cells of strain IMMIB D-1397 ${ }^{\mathrm{T}}$ stained with lactophenol cotton blue, showing rod-shaped cells that cluster together either pole to pole or pole to side. A slide culture was grown on $\mathrm{BHI}$ agar for $6 \mathrm{~h}$ at $36 \pm 1^{\circ} \mathrm{C}$

Spores, capsules, true branching, and aerial hyphae were not observed.

During growth, the cells were primarily long rods (Fig. 1A)pick;0224f1a;0;1 which stuck together, either pole to pole or pole to side (Fig. 2), which resulted in an arrangement that resembled branched hyphae. At an early stage of growth, a septum was formed near one pole of each cell, which resulted in the formation of two asymmetrical parts of the original cell (Fig. 1A). The smaller part elongated, and a new septum was formed near its distal end, which resulted in the formation of a third part (Fig. 1B). This elongation and septum formation were repeated at most three times so that three to four parts originated from one cell. During further incubation these parts separated from each other (Fig. 1C) and, infrequently, began to grow.

Physiological characteristics. The physiological properties of strains IMMIB D-1397 ${ }^{\mathrm{T}}$, IMMIB D-1411, IMMIB D-1437, and IMMIB D-1498 are shown in Table 1. These strains had acetamidase, allantoinase, catalase, $\beta$-glucosidase, $\beta$-galactosidase, nicotinamidase, pyrazinamidase, urease, and phosphatase activities; arylsulfatase, benzamidase, nitrate reductase, and succinamidase activities were not observed. The strains did not produce niacin but tolerated $5 \% \mathrm{NaCl}$ and $p$-nitrobenzoic acid. They grew in the presence of the antituberculosis drugs streptomycin, isoniazid, ethambutol, rifampin, $p$-aminosalicylic acid, protionamide, capreomycin, and cycloserine.

Lipid analysis. The results of one-dimensional thin-layer chromatography and two-dimensional thin-layer chromatography of whole-cell acid and alkaline methanolysates of strains IMMIB D-1397 ${ }^{\mathrm{T}}$, IMMIB D-1411, IMMIB D-1437, and IMMIB D-1498 were similar and are represented by the results obtained for strain IMMIB D-1397 ${ }^{\mathrm{T}}$ in Fig. 3. Two-dimensional thin-layer chromatography resulted in more precise resolution of the components into two mycolate spots in addition to the nonhydroxylated fatty acids (spot F). One-dimensional thin-layer chromatography of the TBDMS ethers of the alkaline methanolysates resulted in identification of the two mycolate spots as $\alpha$ - and $\alpha^{\prime}$-mycolates by their $R_{f}$ values (Fig. 3). A third spot, designated spot X (Fig. 3), was also present in only the alkaline methanolysates of strains IMMIB D-1397 ${ }^{\mathrm{T}}$, IMMIB D-1411, IMMIB D-1437, and IMMIB D-1498, T. paurometabola DSM $20162^{\mathrm{T}}$, T. inchonensis DSM $44067^{\mathrm{T}}$, and $T$. pulmonis DSM $44142^{\mathrm{T}}$. The chemical identity of this spot is not known.

Pyrolysis gas chromatography of the pure $\alpha$-mycolates that were isolated by preparative TLC from strains IMMIB D-1397 ${ }^{\mathrm{T}}$, IMMIB D-1411, IMMIB D-1437, and IMMIB D-1498 released fatty acid methyl esters of $C_{20: 0}, C_{20: 1}, C_{22: 0}$, and $\mathrm{C}_{22: 1}$ as the main pyrolytic cleavage products. Gas chromatographic analyses of the nonhydroxylated fatty acid methyl esters from all of the strains revealed the presence of hexadecanoate, octadecanoate, and tuberculostearic acid (10-methyl octadecanoate) as major fatty acid methyl esters. No 2-methyl branched-chain fatty acids were observed.

A polar lipid analysis showed that the phospholipid type of strains IMMIB D-1397 ${ }^{\text {T }}$, IMMIB D-1411, IMMIB D-1437, and IMMIB D-1498 is type PII sensu Lechevalier et al. (19); i.e., phosphatidylethanolamine is the characteristic phospholipid. Other phospholipids, including phosphatidylinositol, phosphatidylinositol mannoside, and diphosphatidylglycerol, were also detected in all strains. All four strains contained menaquinones MK-8, MK-9, and MK-10; MK-9 was the major component.

16S rDNA sequence analyses. Almost complete $16 \mathrm{~S}$ rDNA sequences comprising 1,468 nucleotides ( $>95 \%$ of the Escherichia coli sequence [3]) were determined for strains IMMIB D-1397 ${ }^{\mathrm{T}}$, IMMIB D-1411, IMMIB D-1437, and IMMIB D-1498. The $16 \mathrm{~S}$ rDNA sequence similarity values generated from a comparison of 1,400 nucleotides between positions 37 and 1482 (E. coli numbering [3]) showed that strain IMMIB D- $1397^{\mathrm{T}}$ was most closely related to the mycolic acid-containing actinomycetes and, more specifically, to members of the genus Tsukamurella (Table 2). With 16S rDNA sequence similarity values ranging from 99.2 to $99.8 \%$, strains IMMIB D-1397 ${ }^{\mathrm{T}}$, IMMIB D-1411, IMMIB D-1437, and IMMIB D-1498 were found to be very closely related to the type strains of $T$. paurometabola, $T$. inchonensis, and T. pulmonis. The four new strains exhibited $16 \mathrm{~S}$ rDNA sequence similarity values ranging from $99.7 \%$ to $100 \%$ to each other. The phylogenetic dendrograms generated reflected the high levels of similarity of the Tsukamurella sequences (data not shown). With such high levels of similarity among the sequences, the branching order within the tight cluster was unstable.

DNA characteristics. Triplicate determinations revealed that the $\mathrm{G}+\mathrm{C}$ contents of the DNAs of strains IMMIB D-1397 ${ }^{\mathrm{T}}$, IMMIB D-1411, IMMIB D-1437, and IMMIB D-1498 were $73.6 \pm 0.03,72.5 \pm 0.02,69.67 \pm 0.02$, and $69.68 \pm 0.15 \mathrm{~mol} \%$, respectively. The levels of relatedness (binding rates) between DNAs of these strains are shown in Table 3, and the levels of relatedness between the DNAs of these organisms and the DNAs of $T$. paurometabola DSM $20162^{\mathrm{T}}$, T. inchonensis DSM $44067^{\mathrm{T}}$, and T. pulmonis DSM $44142^{\mathrm{T}}$ are shown in Table 4.

\section{DISCUSSION}

The $16 \mathrm{~S}$ rDNA sequence comparison clearly showed that strains IMMIB D-1397 ${ }^{\mathrm{T}}$, IMMIB D-1411, IMMIB D-1437, and IMMIB D-1498 are members of the genus Tsukamurella. As demonstrated previously, high levels of 16S rDNA sequence similarity $(>99 \%)$ between Tsukamurella strains do not indicate membership in the same species $(37,38)$. The results of 
TABLE 1. Differential physiological characteristics of strains IMMIB D-1397 ${ }^{\mathbf{T}}$, IMMIB D-1411, IMMIB D-1437, and IMMIB D-1498, T. paurometabola DSM 20162 $2^{\mathrm{T}}$, T. inchonensis DSM 44067 , and T. pulmonis DSM $44142^{\mathrm{T}}$

\begin{tabular}{|c|c|c|c|c|c|c|c|}
\hline Characteristic & $\begin{array}{l}\text { IMMIB } \\
\text { D- } 1397^{\mathrm{T}}\end{array}$ & $\begin{array}{l}\text { IMMIB } \\
\text { D-1411 }\end{array}$ & $\begin{array}{l}\text { IMMIB } \\
\text { D-1437 }\end{array}$ & $\begin{array}{l}\text { IMMIB } \\
\text { D-1498 }\end{array}$ & $\begin{array}{c}T . \\
\text { paurometabola }\end{array}$ & $\begin{array}{c}T . \\
\text { inchonensis }\end{array}$ & $\begin{array}{c}T . \\
\text { pulmonis }\end{array}$ \\
\hline \multicolumn{8}{|l|}{ Hydrolysis of: } \\
\hline Hypoxanthine & + & + & + & + & - & + & - \\
\hline Tyrosine & + & + & + & + & - & -. & - \\
\hline Xanthine & + & + & + & + & - & - & - \\
\hline \multicolumn{8}{|c|}{$\begin{array}{l}\text { Utilization of the following compounds as } \\
\text { sole sources of carbon and energy: }\end{array}$} \\
\hline Maltose & + & - & + & + & - & + & - \\
\hline Cellobiose & - & - & - & - & - & + & - \\
\hline D-Melezitose & + & - & + & + & - & + & - \\
\hline myo-Inositol & + & + & + & t & - & + & - \\
\hline D-Mannitol & + & + & + & + & - & + & + \\
\hline D-Sorbitol & + & + & + & + & - & + & + \\
\hline Acetate & + & + & + & + & - & + & + \\
\hline Benzoate & + & + & + & + & - & - & - \\
\hline Citrate & + & - & + & + & + & + & - \\
\hline Lactate & - & - & - & - & - & + & - \\
\hline$m$-Hydroxybenzoate & - & + & - & - & - & - & - \\
\hline Adipate & + & + & + & + & - & - & - \\
\hline Isoamyl alcohol & + & + & + & + & - & + & + \\
\hline 2,3-Butandiol & + & + & + & + & - & + & + \\
\hline 1,2-Propandiol & + & + & + & + & - & + & + \\
\hline Paraffin & + & + & + & + & - & + & + \\
\hline \multicolumn{8}{|c|}{$\begin{array}{l}\text { Utilization of the following compounds as } \\
\text { sole sources of carbon and nitrogen: }\end{array}$} \\
\hline Acetamide & + & + & + & + & - & + & + \\
\hline L-Alanine & + & + & + & + & - & + & + \\
\hline Gelatin & - & - & - & - & - & - & - \\
\hline Proline & + & + & + & + & - & + & + \\
\hline Serine & - & + & - & - & - & + & - \\
\hline Growth at $45^{\circ} \mathrm{C}$ & - & - & - & - & - & + & - \\
\hline
\end{tabular}

DNA-DNA hybridization studies demonstrated that the four strains are members of the same species, a new species which is distinct from the species currently belonging to the genus Tsukamurella.
The physiological and chemotaxonomic characteristics of isolates IMMIB D-1397 ${ }^{\mathrm{T}}$, IMMIB D-1411, IMMIB D-1437, and IMMIB D-1498 were compared with those of $T$. paurometabola DSM 20162 ${ }^{\mathrm{T}}$, T. inchonensis DSM $44067^{\mathrm{T}}$, and $T$.
A

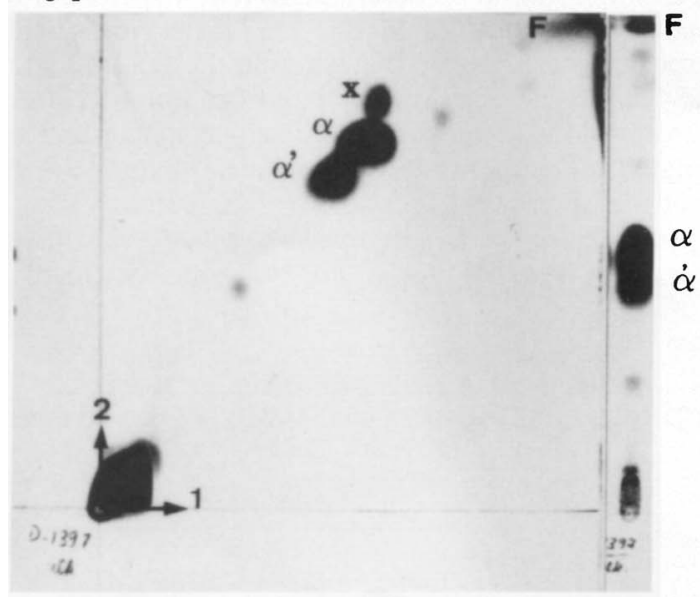

B

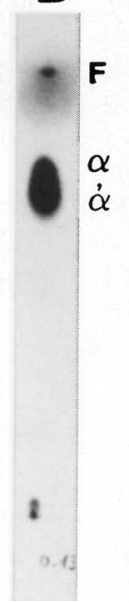

C

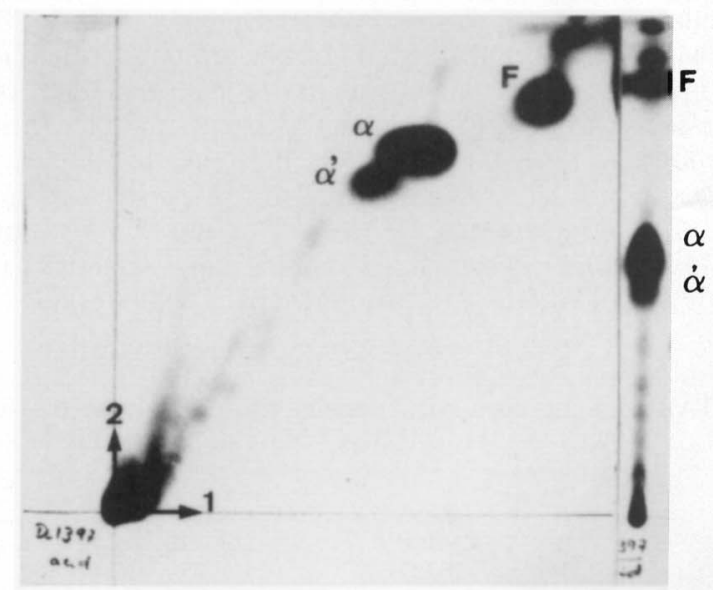

FIG. 3. (A and C) One-dimensional thin-layer chromatography and two-dimensional thin-layer chromatography of whole-cell alkaline (A) and acid (C) methanolysates of strain IMMIB D-1397 T. Triple development in the first direction was with petroleum ether (bp, 60 to $80^{\circ} \mathrm{C}$ )-acetone $(95: 5$, vol/vol), and single development in the second direction was with toluene-acetone (97:3, vol/vol). Abbreviations: $\alpha, \alpha$-mycolate; $\alpha^{\prime}, \alpha^{\prime}$-mycolate; F, nonhydroxylated fatty acid methyl esters. (B) TBDMS ethers of alkaline methanolysates. Single development with petroleum ether (bp, 60 to $\left.80^{\circ} \mathrm{C}\right)$-toluene $\left(70: 30\right.$, vol/vol) was used. $\alpha$ and $\alpha^{\prime}$ indicate TBDMS ethers of the different types of mycolic acid methyl esters. 
TABLE 2. Levels of $16 \mathrm{~S}$ rDNA sequence similarity for strain IMMIB D-1397 ${ }^{\mathrm{T}}$, the type strains of previously described Tsukamurella species, and the type strains of the type species of the mycolic acid-containing genera

\begin{tabular}{|c|c|c|c|c|c|c|c|c|c|}
\hline \multirow[b]{2}{*}{ Organism } & \multicolumn{9}{|c|}{$\% 16 \mathrm{~S}$ rDNA similarity } \\
\hline & 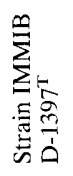 & 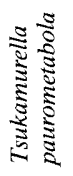 & 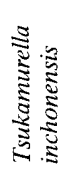 & 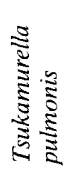 & 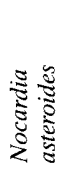 & 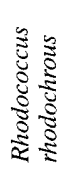 & 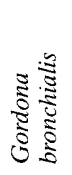 & 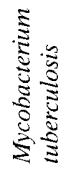 & 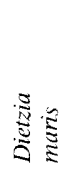 \\
\hline Tsukamurella paurometabola & 99.5 & & & & & & & & \\
\hline Tsukamurella inchonensis & 99.4 & 99.5 & & & & & & & \\
\hline Tsukamurella pulmonis & 99.9 & 99.5 & 99.4 & & & & & & \\
\hline Nocardia asteroides & 94.6 & 94.7 & 94.6 & 94.5 & & & & & \\
\hline Rhodococcus rhodochrous & 94.6 & 94.9 & 94.7 & 94.5 & 94.1 & & & & \\
\hline Gordona bronchialis & 93.6 & 93.7 & 93.6 & 93.6 & 93.7 & 94.6 & & & \\
\hline Mycobacterium tuberculosis & 92.2 & 92.2 & 92.1 & 92.2 & 92.4 & 91.9 & 92.5 & & \\
\hline Dietzia maris & 95.3 & 95.4 & 95.1 & 95.3 & 93.2 & 94.9 & 93.3 & 91.7 & \\
\hline Corynebacterium diphtheriae & 91.4 & 91.2 & 91.2 & 91.3 & 89.5 & 90.5 & 90.5 & 90.1 & 91.0 \\
\hline
\end{tabular}

pulmonis DSM $44142^{\mathrm{T}}$. Chemotaxonomically, strains IMMIB D-1397 ${ }^{\mathrm{T}}$, IMMIB D-1411, IMMIB D-1437, and IMMIB D-1498, T. paurometabola DSM $20162^{\mathrm{T}}$, T. inchonensis DSM $44067^{\mathrm{T}}$, and $T$. pulmonis DSM $44142^{\mathrm{T}}$ are similar. All of these organisms contain galactose and arabinose as characteristic whole-cell sugars in addition to meso-diaminopimelic acid as the wall diamino acid (i.e., they are wall chemotype IV organisms); all contain two mycolic acids corresponding to $\alpha$ - and $\alpha^{\prime}$-mycolates which on pyrolysis release $\mathrm{C}_{20: 0}, \mathrm{C}_{20: 1}, \mathrm{C}_{22: 0}$, and $\mathrm{C}_{22: 1}$ fatty acids as mycolic acid cleavage products; the fatty acid profiles of all seven isolates consist of saturated, unsaturated, and 10-methyl branched fatty acids; and all contain unsaturated menaquinones MK-8, MK-9, and MK-10, with MK-9 as the major component. These chemotaxonomic similarities are supported by the high levels of $16 \mathrm{~S}$ rDNA similarity observed among isolates IMMIB D-1397 ${ }^{\mathrm{T}}$, IMMIB D-1411, IMMIB D-1437, and IMMIB D-1498, T. paurometabola DSM20162 ${ }^{\mathrm{T}}, T$. inchonensis DSM $44067^{\mathrm{T}}$, and T. pulmonis DSM $44142^{\mathrm{T}}$ (Table 2).

In contrast to the chemotaxonomic similarities of isolates IMMIB D-1397 ${ }^{\mathrm{T}}$, IMMIB D-1411, IMMIB D-1437, and IMMIB D-1498, T. paurometabola DSM $20162^{\mathrm{T}}, T$. inchonensis DSM $44067^{\mathrm{T}}$, and T. pulmonis DSM $44142^{\mathrm{T}}$, the results of our physiological tests (Table 1) revealed, on the one hand, clear similarities among strains IMMIB D-1397 ${ }^{\mathrm{T}}$, IMMIB D-1411, IMMIB D-1437, and IMMIB D-1498, although isolate IMMIB D-1411 differs by its inability to utilize maltose, melezitose, and citrate as carbon sources and by its ability to utilize serine as a carbon and nitrogen source. On the other hand, clear differences between these four strains and $T$. paurometabola DSM $20162^{\mathrm{T}}$, T. inchonensis DSM $44067^{\mathrm{T}}$, and T. pulmonis DSM $44142^{\mathrm{T}}$ were observed. Physiologically, isolates IMMIB D-1397 ${ }^{\mathrm{T}}$, IMMIB D-1411, IMMIB D-1437, and IMMIB

TABLE 3. Levels of DNA binding for strains IMMIB D-1397 IMMIB D-1411, IMMIB D-1437, and IMMIB D-1498

\begin{tabular}{lllcl}
\hline \multirow{2}{*}{ Strain } & \multicolumn{4}{c}{$\%$ Binding to: } \\
\cline { 2 - 5 } & IMMIB & IMMIB & IMMIB & IMMIB \\
& D-1397 & D-1411 & D-1437 & D-1498 \\
\hline IMMIB D-1397 $^{\text {T }}$ & & 85.3 & 88.8 & 94.3 \\
IMMIB D-1411 & 85.3 & & 85.0 & 78.55 \\
IMMIB D-1437 & 88.8 & 77.55 & & 94.3 \\
IMMIB D-1498 & 89.66 & 78.55 & 94.3 & \\
\hline
\end{tabular}

D-1498 differ from T. paurometabola DSM 20162 ${ }^{\mathrm{T}}$, T. inchonensis DSM $44067^{\mathrm{T}}$, and T. pulmonis DSM $44142^{\mathrm{T}}$ by their ability to hydrolyze tyrosine and xanthine and their ability to assimilate benzoate and adipate as carbon sources. $T$. paurometabola DSM $20162^{\mathrm{T}}$ and $T$. pulmonis DSM $44067^{\mathrm{T}}$ differ from isolates IMMIB D-1397 ${ }^{\mathrm{T}}$, IMMIB D-1411, IMMIB D-1437, and IMMIB D-1498 by not hydrolyzing hypoxanthine and not utilizing inositol as a carbon source. $T$. inchonensis DSM $44067^{\mathrm{T}}$ resembles strains IMMIB D-1397 ${ }^{\mathrm{T}}$, IMMIB D-1411, IMMIB D-1437, and IMMIB D-1498 in its ability to hydrolyze hypoxanthine and its ability to assimilate maltose, melezitose, and inositol as carbon sources. Other differences among the strains studied are shown in Table 1.

The physiological similarities among strains IMMIB D-1397 ${ }^{\mathrm{T}}$, IMMIB D-1411, IMMIB D-1437, and IMMIB D-1498 are supported by the high levels of hybridization among the DNAs of these strains (Table 3). The physiological differences between these strains and $T$. paurometabola DSM $20162^{\mathrm{T}}, T$. inchonensis DSM $44067^{\mathrm{T}}$, and $T$. pulmonis DSM $44142^{\mathrm{T}}$ are supported by the low levels of hybridization between the DNAs (Table 4).

We therefore propose that strains IMMIB D-1397 ${ }^{\mathrm{T}}$, IMMIB D-1411, IMMIB D-1437, and IMMIB D-1498 belong to a single species that should be described as a new species of the genus Tsukamurella. Strain IMMIB D-1397 is the type strain of this new species and has been deposited in the DSM as strain DSM 44234. The type strain was isolated from blood cultures from a 62-year-old woman with a cardiac pacemaker implant. It was isolated more than once from clinical material. A description of this species is given below.

Description of Tsukamurella tyrosinosolvens sp. nov. Tsukamurella tyrosinosolvens (ty. ro. si. no. sol' vens. Gr. masc. n.

TABLE 4. Levels of DNA binding for strains IMMIB D-1397 ${ }^{\mathrm{T}}$, IMMIB D-1411, IMMIB D-1437, and IMMIB D-1498 and other members of the genus Tsukamurella

\begin{tabular}{lccc}
\hline \multirow{2}{*}{ Strain } & \multicolumn{3}{c}{$\%$ Binding to: } \\
\cline { 2 - 4 } & $\begin{array}{c}\text { T. paurometabola } \\
\text { DSM 20162 }\end{array}$ & $\begin{array}{c}\text { T. inchonensis } \\
\text { DSM 44067 }\end{array}$ & $\begin{array}{r}\text { T. pulmonis } \\
\text { DSM 44142 }\end{array}$ \\
\hline IMMIB D-1397 & 53.4 & 53.5 & 54.7 \\
IMMIB D-1411 & 39.8 & 59.7 & 54.7 \\
IMMIB D-1437 & 45.44 & 61.88 & 58.0 \\
IMMIB D-1498 & 47.85 & 65.74 & 66.8 \\
\hline
\end{tabular}


tyros, cheese; tyrosine, an amino acid; L. pres. part. solvens, dissolving; M. L. adj. tyrosinosolvens, tyrosine dissolving, referring to the hydrolysis of tyrosine which is characteristic of this species). Cells are aerobic, gram-positive, and slightly acidalcohol-fast bacilli. Most cells are long rods that, at a late stage of growth, fragment into three parts which then separate and grow as independent rods. The cells do not form spores, capsules, or aerial hyphae. Visible growth from dilute inocula occurs within 2 days; colonies on BHI agar are yellowish, dry, and rough. Growth occurs at 24,31 , and $37^{\circ} \mathrm{C}$ but not at $45^{\circ} \mathrm{C}$. The organism contains meso-diaminopimelic acid as the wall diamino acid in addition to galactose and arabinose in wholecell hydrolysates (i.e., the cell wall chemotype is chemotype IV). It has a type $\alpha, \alpha^{\prime}$ mycolate pattern and a type PII phospholipid pattern with significant amounts of phosphatidylethanolamine. Menaquinone MK-9 is the major menaquinone, and minor amounts of menaquinones MK-8 and MK-10 are also present. Melanoid pigments are not produced on either ISP medium 6 or ISP medium 7. Produces acetamidase, allantoinase, catalase, $\beta$-glucosidase, $\beta$-galactosidase, nicotinamidase, pyrazinamidase, urease, and phosphatase but not arylsulfatase (after 3 days), benzamidase, nitrate reductase, and succinamidase. Grows on MacConkey agar without crystal violet and tolerates $5 \% \mathrm{NaCl}$ and $p$-nitrobenzoic acid. Niacin is not produced. Resistant to lysozyme. D-Glucose, galactose, maltose, trehalose, sucrose, D-melezitose, myo-inositol, D-mannitol, D-sorbitol, acetate, benzoate, citrate, gluconate, adipate, isoamyl alcohol, 2,3-butandiol, 1,2-propandiol, and paraffin are utilized as sole carbon sources, but L-arabinose, D-xylose, Lrhamnose, lactose, raffinose, cellobiose, adonitol, meso-erythritol, lactate, $m$-hydroxybenzoate, and $p$-hydroxybenzoate are not utilized. Acetamide, L-alanine, and proline are utilized as nitrogen and carbon sources, but gelatin and serine are not utilized. Hypoxanthine, tyrosine, xanthine, urea, esculin, and Tween 80 are hydrolyzed, but adenine, casein, gelatin, elastin, guanine, keratin, and testosterone are not hydrolyzed. Acid is produced from D-glucose, D-galactose, maltose, trehalose, sucrose, mannose, D-melezitose, myo-inositol, D-mannitol, D-sorbitol, and fructose, but not from L-arabinose, D-xylose, L-rhamnose, lactose, raffinose, cellobiose, adonitol, and inulin. Resistant to streptomycin, isoniazid, ethambutol, rifampin, $p$ aminosalicylic acid, protionamide, capreomycin, and cycloserine. The $\mathrm{G}+\mathrm{C}$ content of the type strain is $73.6 \pm 0.03$ mol\%, and the $\mathrm{G}+\mathrm{C}$ contents of the species range from 69 to 74 mol\%. The type strain is strain IMMIB D-1397 (= DSM 44234).

\section{ACKNOWLEDGMENT}

We thank Claudine Strack (Alfried-Krupp Laboratory) for preparing the phase-contrast and electron micrographs.

\section{REFERENCES}

1. Becker, B., M. P. Lechevalier, R. E. Gordon, and H. A. Lechevalier. 1964 Rapid differentiation between Nocardia and Streptomyces by paper chromatography of whole cell hydrolysates. Appl. Microbiol. 12:421-423.

2. Bönicke, R. 1962. Identification of mycobacteria by biochemical methods Bull. Int. Union Tuberc. 32:13-86.

3. Brosius, J., M. L. Palmer, P. J. Kennedy, and H. F. Noller. 1978. Complete nucleotide sequence of the 16S ribosomal RNA gene from Escherichia coli. Proc Natl. Acad. Sci. USA 75:4801-4805.

4. Cashion, P., M. A. Holder-Franklin, J. McCully, and M. Franklin. 1977. A rapid method for the base ratio determination of bacterial DNA. Anal. Biochem. 81:461-466.

5. Collins, M. D., and D. Jones. 1982. Lipid composition of Corynebacterium paurometabolum (Steinhaus). FEMS Microbiol. Lett. 13:13-16.

6. Collins. M. D., T. Pirouz, M. Goodfellow, and D. E. Minnikin. 1977. Distribution of menaquinones in actinomycetes and corynebacteria. J. Gen. Microbiol. 100:221-230.
7. Collins, M. D., J. Smida, M. Dorsch, and E. Stackebrandt. 1988. Tsukamurella gen. nov. harboring Corynebacterium paurometabolum and Rhodococcus aurantiacus. Int. J. Syst. Bacteriol. 38:385-391.

8. Goodfellow, M., P. A. B. Orlean, M. D. Collins, L. Alshamaony, and D. E. Minnikin. 1978. Chemical and numerical taxonomy of strains received as Gordona aurantiaca. J. Gen. Microbiol. 109:57-68.

9. Gordon, R. E. 1966. Some criteria for the recognition of Nocardia madurae (Vincent) Blanchard. J. Gen. Microbiol. 45:355-364.

10. Gordon, R. E., and J. M. Mihm. 1957. A comparative study of some strains received as nocardiae. J. Bacteriol. 73:15-27.

11. Gordon, R. E., and M. M. Smith. 1955. Proposed group of characters for the separation of Streptomyces and Nocardia. J. Bacteriol. 69:147-150.

12. Felsenstein, J. 1993. Phylogenetic inference package, version 3.5.1. Depart ment of Genetics, University of Washington, Seattle.

13. Kilburn, J. O., and G. P. Kubica. 1968. Reagent impregnated paper strips for detection of niacin. Am. J. Clin. Pathol. 50:530-532.

14. Kubica, G. P., and H. L. David. 1980. The mycobacteria, p. 1693-1730. In A. C. Sonnenwirth and L. Jarett (ed.), Gradwohl's clinical laboratory methods and diagnosis. The C. V. Mosby Co., St. Louis, Mo.

15. Kubica, G. P., W. E. Dye, M. L. Cohn, and G. Middlebrook. 1963. Sputum digestion and decontamination with $\mathrm{N}$-acetyl-L-cysteine-sodium hydroxide for culture of mycobacteria. Am. Rev. Respir. Dis. 87:775-779.

16. Kubica, G. P., and G. L. Pool. 1960. Studies on the catalase activity of acid fast bacilli. I. An attempt to subgroup these organisms on the basis of their catalase activities at different temperatures and pH. Am. Rev. Respir. Dis. 81:387-391.

17. Kubica, G. P., and A. L. Ridgon. 1961. The arylsulfatase activity of acid-fast bacilli. III. Preliminary investigation of rapidly growing acid-fast bacilli. Am. Rev. Respir. Dis. 83:737-740.

18. Lechevalier, M. P. 1968. Identification of aerobic actinomycetes of clinical importance. J. Lab. Clin. Med. 71:934-944.

19. Lechevalier, M. P., C. de Bievere, and H. A. Lechevalier. 1977. Chemotaxonomy of aerobic actinomycetes: phospholipid composition. Biochem. Syst. Ecol. 5:249-260.

20. Lechevalier, M. P., and H. A. Lechevalier. 1970. Chemical composition as a criterion in the classification of aerobic actinomycetes. Int. J. Syst. Bacteriol. 20:435-443.

21. Maidak, B. L., N. Larsen, M. J. McCaughey, R. Overbeek, G. J. Olsen, K. Fogel, J. Blandy, and C. R. Woese. 1994. The Ribosomal Database Project. Nucleic Acids Res. 22:3485-3487.

22. Mesbah, M., U. Premachandran, and W. B. Whitman. 1989. Precise measurement of the $\mathrm{G}+\mathrm{C}$ content of deoxyribonucleic acid by high-performance liquid chromatography. Int. J. Syst. Bacteriol. 39:159-167.

23. Pattyn, S. R., and F. Portaels. 1972. Identification and clinical significance of mycobacteria. Zentralbl. Bakteriol. Parasitenkd. Infektionskr. Hyg. Abt. 1 Orig. Reihe A 219:114-140.

24. Rainey, F. A., J. Burghardt, R. M. Kroppenstedt, S. Klatte, and E. Stackebrandt. 1995. Polyphasic evidence for the transfer of Rhodococcus roseus to Rhodococcus rhodochrous. Int. J. Syst. Bacteriol. 45:101-103.

25. Rainey, F. A., N. Ward-Rainey, R. M. Kroppenstedt, and E. Stackebrandt. 1996. The genus Nocardiopsis represents a phylogenetically coherent taxon and a distinct actinomycete lineage: proposal of Nocardiopsiaceae fam. nov. Int. J. Syst. Bacteriol. 46:1088-1092.

26. Shirling, E. B., and D. Gottlieb. 1966. Methods for characterization of Streptomyces species. Int. J. Syst. Bacteriol. 16:313-340.

27. Sommers, H. M., and R. C. Good. 1985 . Mycobacterium, p. 216-248. In E. H. Lennette, A. Balows, W. J. Hausler, Jr., and H. J. Shadomy (ed.), Manual of clinical microbiology, 4th ed. American Society for Microbiology, Washington, D.C.

28. Tomoysau, I., and I. Yano. 1984. Separation and analysis of novel polyunsaturated mycolic acids from a psychrophilic, acid-fast bacterium, Gordona aurantiaca. Eur. J. Biochem. 139:173-180.

29. Tsukamura, M. 1974. Differentiation of the 'Mycobacterium' rhodochrousgroup from nocardiae by $\beta$-galactosidase activity. J. Gen. Microbiol. 80:553555

30. Tsukamura, M., and S. Tsukamura. 1965. Differentiation of Mycobacterium tuberculosis and Mycobacterium bovis by $p$-nitrobenzoic acid susceptibility Tubercle 45:64-65

31. Wayne, L. G., H. C. Engbaek, H. W. B. Engel, S. Froman, W. Gross, J. Hawkins, W. Käppler, A. G. Karlson, H. H. Kleeberg, I. Krasnow, G. P. Kubica, C. McDurmont, E. E. Nel, S. R. Pattyn, K. H. Schröder, S. Showalter, I. Tarnock, M. Tsukamura, B. Vergman, and E. Wolinsky. 1974. Highly reproducible techniques for use in systematic bacteriology in the genus Mycobacterium: tests for pigment, urease, resistance to sodium chloride, hydrolysis of Tween 80, and $\beta$-galactosidase. Int. J. Syst. Bacteriol. 24:412419.

32. Wayne, L. G., H. W. B. Engel, C. Grassi, W. Gross, J. Hawkins, P. A. Jenkins, W. Käppler, H. H. Kleeberg, I. Krasnow, E. E. Nel, S. R. Pattyn, P. A. Richards, S. Showalter, M. Slosarek, I. Szabo, I. Tarnok, M. Tsukamura, B. Vergmann, and E. Wolinsky. 1976. Highly reproducible techniques for use in systematic bacteriology in the genus Mycobacterium: tests for niacin and 
catalase and for resistance to isonizid, thiophene, 2-carboxylic acid hydrazide, hydroxylamine, and p-nitrobenzoate. Int. J. Syst. Bacteriol. 26:311-318.

33. Yamada, Y., G. Inouye, Y. Tahara, and K. Kondo. 1976. The menaquinone system in the classification of coryneform and nocardioform bacteria and related organisms. J. Gen. Appl. Microbiol. 22:203-214.

34. Yassin, A. F., C. Binder, and K. P. Schaal. 1993. Identification of mycobacterial isolates by thin-layer and capillary gas-liquid chromatography under diagnostic routine conditions. Zentralbl. Bakteriol. Parasitenkd. Infektionskr. Hyg. Abt. 1 Orig. 278:34-48.

35. Yassin, A. F., E. A. Galinski, A. Wohlfarth, K.-D. Jahnke, K. P. Schaal, and H. G. Trüper. 1993. A new actinomycete species, Nocardiopsis lucentensis sp. nov. Int. J. Syst. Bacteriol. 43:266-271.

36. Yassin, A. F., B. Haggenei, H. Budzikiewicz, and K. P. Schaal. 1993. Fatty acid and polar lipid composition of the genus Amycolatopsis: application of fast atom bombardment-mass spectrometry to structure analysis of underivatized phospholipids. Int. J. Syst. Bacteriol. 43:414-420.

37. Yassin, A. F., F. A. Rainey, H. Brzezinka, J. Burghardt, H. L. Lee, and K. P. Schaal. 1995. Tsukamurella inchonensis sp. nov. Int. J. Syst. Bacteriol. 45: $522-527$.

38. Yassin, A. F., F. A. Rainey, H. Brzezinka, J. Burghardt, M. Rifai, P. Seifert K. Feldmann, and K. P. Schaal. 1996. Tsukamurella pulmonis sp. nov. Int. J. Syst. Bacteriol. 46:429-436. 